\title{
IMPORT SUBSTITUTION IN THE AGRO-INDUSTRIAL COMPLEX: IMPLEMENTATION MECHANISM AND DEVELOPMENT PROSPECTS
}

\author{
Natalya V. Gorshkova \\ Volgograd State University, Volgograd, Russian Federation \\ Ekaterina A. Shkarupa \\ Volgograd State University, Volgograd, Russian Federation \\ Aleksej V. Eltoncev \\ Volgograd State University, Volgograd, Russian Federation
}

\begin{abstract}
The problems and prospects of the import substitution policy continue to be a strategic priority for the development of the Russian economy. This is due to the presence of imports of certain types of food, which pose a threat to the food security of the territory and the infringement of national interests of the country. The current state support of the agro-industrial complex is aimed at increasing agricultural production in order to ensure import substitution. All this determines the need to improve the process of supporting the agro-industrial complex, create favorable conditions for the effective development of rural areas, increase the financial stability of agricultural producers, ensure a sufficient level of their profitability, create and develop a full-fledged production infrastructure. The purpose of this study is to consider the mechanism for the implementation of import substitution in the agroindustrial complex and possible prospects for its development in modern conditions. The article presents an overview of the existing interpretations of the "import substitution" concept which made it possible to indicate the author's position regarding the studied phenomenon. The mechanism of import substitution is manifested in the unity of its component mechanisms: organizational and economic, which in turn include certain forms, methods, tools. The potential for further development of the agro-industrial complex import substitution mechanism is represented by the following directions: expansion of grant financing of agro-industrial complex enterprises, the list of targeted preferential short-term lending, strengthening of tax incentives, implementation of projects based on public-private partnership.

Key words: agro-industrial complex, state support, import substitution, food security, subsidies, financing, tax incentives, public-private partnership.

Citation. Gorshkova N.V., Shkarupa E.A., Eltoncev A.V. Import Substitution in the Agro-Industrial Complex: Implementation Mechanism and Development Prospects. Vestnik Volgogradskogo gosudarstvennogo universiteta. Ekonomika [Journal of Volgograd State University. Economics], 2021, vol. 23, no. 3, pp. 63-73. (in Russian). DOI: https://doi.org/10.15688/ek.jvolsu.2021.3.6

ИМПОРТОЗАМЕЩЕНИЕ В АПК: МЕХАНИЗМ РЕАЛИЗАЦИИ И ПЕРСПЕКТИВЫ РАЗВИТИЯ

\author{
Наталья Валерьевна Горшкова
}

Волгоградский государственный университет, г. Волгоград, Российская Федерация

\section{Екатерина Александровна Шкарупа}

Волгоградский государственный университет, г. Волгоград, Российская Федерация 


\section{Алексей Викторович Елтонцев}

Волгоградский государственный университет, г. Волгоград, Российская Федерация

Аннотация. Проблемы и перспективы проведения политики импортозамещения продолжают оставаться стратегическим приоритетом развития российской экономики. Это обусловлено присутствием импорта отдельных видов продовольствия, создающих угрозу продовольственной безопасности территории и национальным интересам страны. Реализуемая в настоящее время государственная поддержка АПК направлена на увеличение сельскохозяйственной продукции с целью обеспечения импортозамещения. Все это обусловливает необходимость совершенствования процесса поддержки агропромышленного комплекса, создания благоприятных условий для эффективного развития сельских территорий, повышения финансовой устойчивости сельскохозяйственных товаропроизводителей, обеспечения достаточного уровня их доходности, формирования и развития полноценной производственной инфраструктуры. Целью данной работы является рассмотрение механизма реализации импортозамещения в АПК и возможных перспектив его развития в современных условиях. В статье представлен обзор имеющихся интерпретаций понятия «импортозмещение», который позволил обозначить авторскую позицию в отношении исследуемого явления. Механизм импортозамещения проявляется в единстве его составляющих - организационного и экономического механизмов, включающих, в свою очередь, определенные формы, методы, инструменты. Потенциал возможностей дальнейшего развития механизма импортозамещения АПК представлен следующими направлениями: расширением сферы грантового финансирования предприятий АПК, перечнем целевого льготного краткосрочного кредитования, усилением налогового стимулирования, реализацией проектов на основе государственно-частного партнерства.

Ключевые слова: агропромышленный комплекс, государственная поддержка, импортозамещение, продовольственная безопасность, субсидирование, финансирование, налоговое стимулирование, государственно-частное партнерство.

Цитирование. Горшкова Н. В., Шкарупа Е. А., Елтонцев А. В. Импортозамещение в АПК: механизм реализации и перспективы развития // Вестник Волгоградского государственного университета. Экономика. -2021. - Т. 23, № 3. - С. 63-73. - DOI: https://doi.org/10.15688/ek.jvolsu.2021.3.6

\section{Введение}

Полученный урожай и объемы животноводческой продукции в 2020 г. позволили внести существенный вклад в обеспечение продовольственной независимости Российской Федерации и импортозамещения.

Объективная необходимость в проведении политики импортозамещения в АПК обусловлена присутствием импорта отдельных видов продовольствия, создающих угрозу продовольственной безопасности территории и национальным интересам страны. Согласимся, что «сохранение экзогенных, эндогенных вызовов и угроз актуализирует задачу поддержания продовольственной безопасности России и еe регионов, это объясняет внимание к вопросам импортозамещения по основным видам сельскохозяйственной продукции в российском АПК» [Чернова и др., 2018, с. 41].

Цель исследования заключается в рассмотрении механизма реализации импортозамещения в АПК и возможных перспектив его развития в современных условиях.

\section{Варианты трактовки}

\section{понятия «импортозамещение»}

Однозначного толкования понятие «импортозамещение» так и не получило. Этот процесс характеризуется своей активностью и постоянным движением, различные этапы которого определяют стратегию государства и глобальные геополитические тенденции.

Особенности политики импортозамещения и проблемы ее реализации продолжают исследовать многие российские ученые. Авторы осуществляют попытки изучения новых подходов к определению понятия «импортозамещение».

Актуальным продолжает оставаться положение меркантилистов о том, что «импортозамещение не должно ограничиваться лишь размерами внутреннего рынка». Политика импортозамещения в АПК предполагает производство качественной и современной продукции, результатами которого должны стать ее экспорт и повышение конкурентоспособности на международном рынке. 
В экономической литературе можно встретить подход, предполагающий изучение понятия «импортозамещение» как процесса.

В.К. Фальцман определяет импортозамещение как «естественный процесс развития и экономического роста, модернизации, преодоления накопленного научно-технического отставания и повышения конкурентоспособности отечественной продукции» [Фальцман, 2015 , с. 23]. Автором подчеркивается, что чрезвычайные обстоятельства предопределяют поиск новых путей форсирования процесса импортозамещения.

Г.А. Федосеева отмечает, что импортозамещение - это «процесс качественных преобразований в экономике государства, направленный на развитие производства товаров, аналогичных поставляемым на внутренний рынок из-за рубежа, связанный с повышением конкурентоспособности выпускаемой продукции, национальных товаропроизводителей и страны в целом для достижения перспективного инновационного роста» [Федосеева, 2015, c. 147].

Ссылаясь на трактовку О.Б. Березинской и А.Л. Ведева, понимаем, что они также придерживаются позиции, что это «процесс последовательного вытеснения импортных сырья, материалов, покупных изделий на более низкие производственные уровни» [Березинская и др., 2015, с. 114].

Отметим довольно простое понимание авторов (Э.Ф. Баранов, Н.Н. Волкова, А.Ф. Лобзов), которые рассматривают импортозамещение как «процесс сокращения или прекращения импорта отдельных товаров и замещение их на внутреннем рынке страны аналогичными отечественными» [Баранов и др., 2013, с. 8].

Схожее мнение присутствует в работах таких авторов, как: Г.И. Идрисов, П.А. Кадочников, С.Г. Синельников-Мурылев. Под импортозамещением они понимают «увеличение производства и внутреннего потребления отечественных товаров при снижении потребления импортных товаров (в физическом выражении)» [Идрисов и др., 2010].

Отдельными учеными при определении понятия «импортозамещение» делается акцент на политической составляющей. Так, О. Старовойтова считает, что импортозамещение представляет собой «часть протекци- онистской политики, направленной не на дискриминацию импорта, а на стимулирование национального производства и производителя с целью вытеснения импорта за счет производства конкурентоспособной продукции, достижения самообеспечения и переориентации спроса национального потребителя» [Старовойтова, 2011, с. 11].

Д.А. Смирнов считает, что это «политика государства или отдельных институтов, направленная на замещение в закупках высокотехнологичной продукции зарубежного производства отечественными аналогами путем стимулирования локализации производства и трансфера технологий» [Смирнов, 2012, с. 37].

Н.А. Сучкова считает, что импортозамещение - «особый тип экономической стратегии и промышленной политики государства, направленный на замену импорта пользующихся спросом на внутреннем рынке промышленных товаров товарами национального производства». То есть импортозамещению свойственен «плановый процесс насыщения внутреннего рынка на основе развития национального производства» [Сучкова, 2009, с. 23].

М.Ю. Лявина в своем диссертационном исследовании обосновывает необходимость трактовки данного понятия в широком и узком смыслах. Справедливо отмечено, что с позиции широкого смысла импортозамещение представлено полным включением страны в систему международного разделения труда, с позиции узкого смысла подразумевается замена на отечественные товары импортных [Лявина, 2021].

Проведенный анализ определений позволил выделить доминирующий подход авторов к изучению импортозамещения как процесса. Имеют место мнения авторов о представлении данного феномена с позиции политики, стратегии и как экономической категории.

\section{Механизм реализации импортозамещения в АПК: современные тренды}

Реализация политики импортозамещения в АПК предполагает формирование и развитие механизма, позволяющего повысить конкурентоспособность отечественной продукции АПК. Определяя данный механизм как сис- 


\section{УПРАВЛЕНИЕ ЭКОНОМИЧЕСКИМ РАЗВИТИЕМ}

тему обеспечения агропродовольственного импортозамещения, М.Ю. Лявина справедливо отмечает, что она позволит «выйти на качественно новый уровень разрешения противоречий, возникающих в процессе реализации агропродовольственного импортозамещения» [Лявина, 2021, с. 137-138].

Механизм импортозамещения в АПК проявляется в единстве его составляющих механизмов (блоков) - организационного и экономического, включающих, в свою очередь, определенные формы, методы, инструменты (рис. 1). Для поддержки сельскохозяйственных товаропроизводителей государством предусмотрены следующие меры: субсидирование, кредитование, страхование, налогообложение, информационное обеспече- ние производителей, проведение закупочных интервенций и др.

Данные направления отражены в реализуемой «Государственной программе развития сельского хозяйства и регулирования рынков сельскохозяйственной продукции, сырья и продовольствия», пролонгированной до 2025 г., которая выступает основополагающим документом реализации механизма импортозамещения в России.

Поддержка отраслей АПК, обеспечивающих ускоренное импортозамещение, реализуется в рамках ведомственного проекта «Развитие отраслей агропромышленного комплекса, обеспечивающих ускоренное импортозамещение основных видов сельскохозяйственной продукции, сырья и продовольствия» ука-

\begin{tabular}{|c|c|}
\hline Цель & Механизм импортозамещения в АПК \\
\hline \multicolumn{2}{|c|}{ Укрепление природно-ресурсного и развитие научно-технического потенциала страны } \\
\hline \multicolumn{2}{|l|}{$\downarrow$} \\
\hline \multicolumn{2}{|c|}{$\begin{array}{l}\text { Улучшение социальных условий жизни сельского населения, обеспечение } \\
\text { достаточного уровня доходности сельскохозяйственных товаропроизводителей }\end{array}$} \\
\hline Экономический механизм & Организационный механизм \\
\hline $\begin{array}{l}\text { Финансирование (софинансирование, } \\
\text { целевое финансирование, проектное } \\
\text { финансирование, возможности госу- } \\
\text { дарственно-частного партнерства), } \\
\text { кредитование, субсидирование, тамо- } \\
\text { женно-тарифное регулирование, нало- } \\
\text { гообложение, грантовая поддержка }\end{array}$ & $\begin{array}{l}\text { Информационное и научно-техническое } \\
\text { обеспечение, предоставление консуль- } \\
\text { тационной поддержки, поддержка на- } \\
\text { учно-технической и инновационной } \\
\text { деятельности, государственные закупки } \\
\text { и государственный заказ, развитие сис- } \\
\text { темы государственных гарантий, фор- } \\
\text { мирование и развитие инфраструктуры } \\
\text { АПК, развитие системы сельскохозяй- } \\
\text { ственной кооперации, меры по продви- } \\
\text { жению отечественных товаров на рын- } \\
\text { ках, в том числе рекламного характера, } \\
\text { реализуемые на уровне государства, } \\
\text { формирование условий для продвиже- } \\
\text { ния товаров }\end{array}$ \\
\hline
\end{tabular}

\begin{tabular}{|c|c|}
\hline & Ожидаемые результаты \\
\hline \multirow[t]{2}{*}{$\begin{array}{l}\text { Создание новых пред- } \\
\text { приятий и производств, } \\
\text { появление новых рабо- } \\
\text { чих мест, повышение } \\
\text { занятости населения, } \\
\text { преимущественно сель- } \\
\text { ских территорий }\end{array}$} & $\begin{array}{l}\text { Повышение конкурентоспособности отечественной про- } \\
\text { дукции за счет стимулирования технологической модерн- } \\
\text { зации производства, повышения его эффективности и ос- } \\
\text { воения новых конкурентоспособных видов продукции с } \\
\text { относительно высокой добавленной стоимостью }\end{array}$ \\
\hline & Укрепление экономической безопасности страны \\
\hline
\end{tabular}

Рис. 1. Содержание механизма импортозамещения в АПК

Примечание. Составлено авторами. 
занной программы. Основные задачи, от решения которых зависит достижение цели ускоренного импортозамещения, представлены ростом объемов производства продукции приоритетных видов отраслей животноводства и растениеводства, пищевой и перерабатывающей промышленности, увеличением площадей многолетних насаждений и виноградников.

Так, основным инструментом реализации механизма импортозамещения выступают субсидии из федерального бюджета (компенсирующая направлена на поддержку отдельных подотраслей растениеводства и животноводства, сельскохозяйственное страхование; стимулирующая - на развитие приоритетных подотраслей АПК и малых форм хозяйствования).

По состоянию на 1 января 2021 г. сельскохозяйственным товаропроизводителям в рамках «компенсирующей» субсидии перечислено 34 277,7 млн рублей (99,92 \% от годового лимита), в рамках «стимулирующей» субсидии - 27 112,8 млн рублей $(99,93$ \% от годового лимита).

За 2020 г. производство скота и птицы на убой (в живом весе) в хозяйствах всех категорий, по данным Росстата, составило 15,64 млн тонн, что на 3,1 \% (+471,5 тыс. тонн) больше уровня 2019 года. В том числе в сельскохозяйственных организациях производство увеличилось на 4,5\%, крестьянских (фермерских) хозяйствах - на 3,2 \%, а в хозяйствах населения оно уменьшилось на 2,5\%.
Так, численность товарного поголовья коров специализированных мясных пород имеет тенденцию к увеличению - на 7,8 \% больше, чем в 2019 году (рис. 2). Такая динамика свидетельствуют о создании базы для дальнейшего развития отечественного мясного скотоводства, что способствует ускоренному импортозамещению.

Положительная динамика показателей наблюдается в структуре производства скота и птицы на убой. За последние 5 лет доля свиней на убой возросла с 29,5 до 35 \%. Стремительное развитие скороспелых подотраслей животноводства - мясного птицеводства и свиноводства - способствует увеличению производства мяса птицы и свинины, обеспечению их устойчивого импортозамещения [Национальный доклад ..., , 2021].

Производство продукции растениеводства в части зерна и пшеницы также характеризуется положительной тенденцией. В 2020 г. валовой сбор зерна превысил на 10,1 \% показатели уровня 2019 г. и составил 133,5 млн тонн (см. рис. 3). В топ-регионы вошла и Волгоградская область, собрав за 2020 г. 5,1 млн тонн зерна. Увеличение посевной площади с 28,1 млн га в 2019 г. до 29,4 млн га в 2020 г. обеспечило рост валового сбора озимой и яровой пшеницы на 15,4 \%.

Кредитование продолжает оставаться доминирующим инструментом поддержки отраслей АПК. АО «Россельхозбанк», оста-

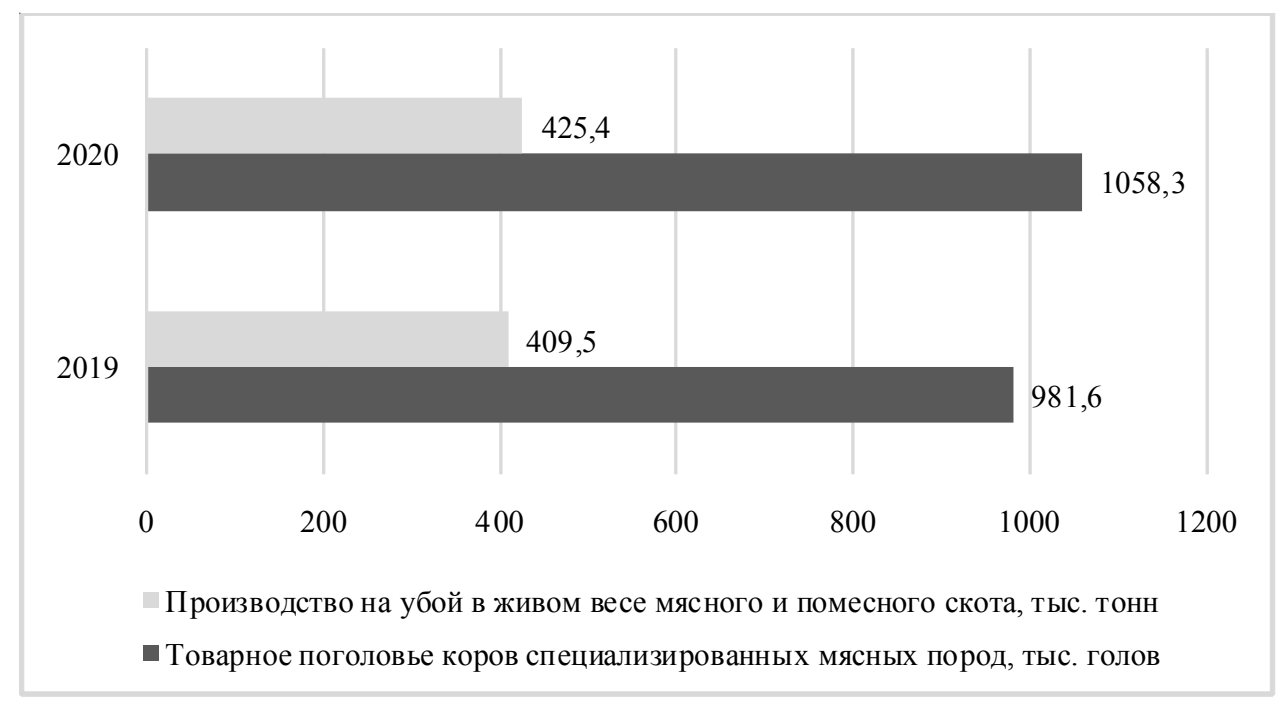

Рис. 2. Развитие мясного скотоводства в Российской Федерации

Примечание. Составлено авторами по: [Национальный доклад ... , 2021]. 


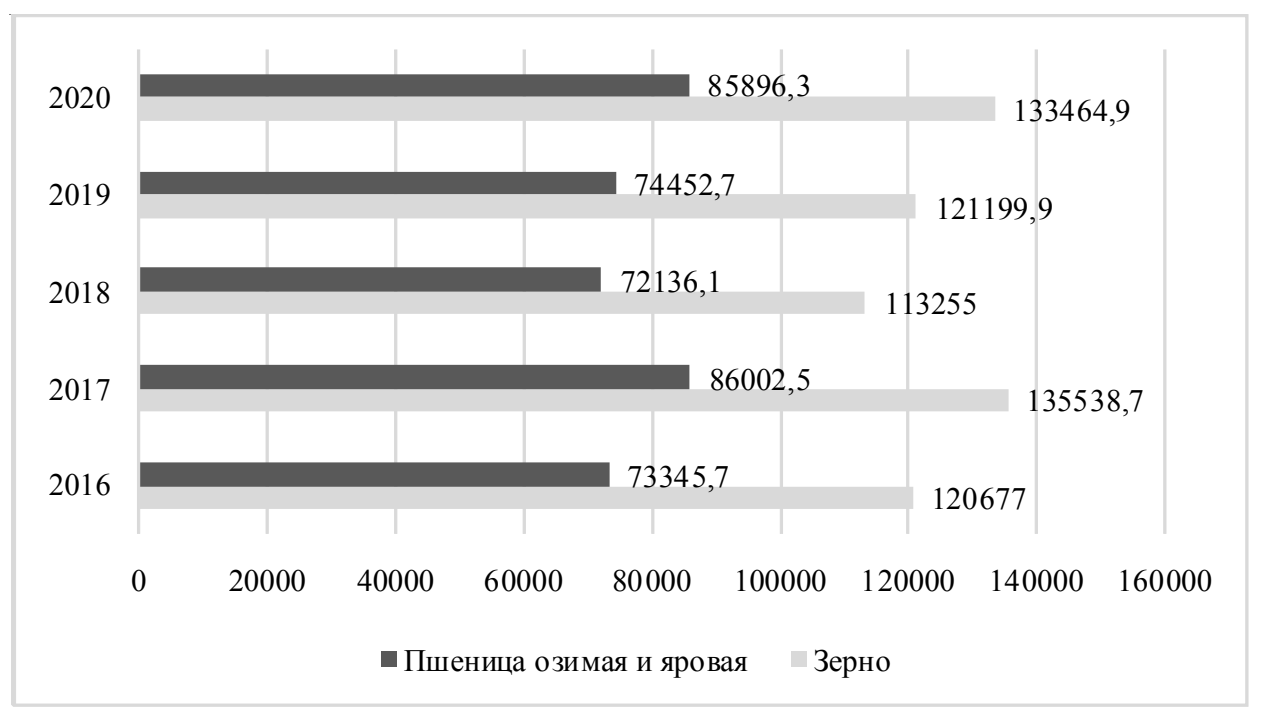

Рис. 3. Производство продукции растениеводства, тонн

Примечание. Составлено авторами по: [Национальный доклад ... , 2021].

ваясь лидером в кредитовании (72\%), обеспечивает реализацию механизмов поддержки отрасли, поддерживает стабильность производства продукции АПК и содействует решению задач по ускоренному импортозамещению.

Наиболее востребованным в АПК остается механизм льготного кредитования. Общая сумма перечисленных в 2019 г. субсидий по льготным кредитам составила 66,17 млрд рублей, в 2020 г. - 61,83 млрд рублей.

Следует отметить, что помимо прямых субсидий поддержка агропромышленного комплекса оказывается путем реализации косвенных мер государственной поддержки, в том числе налоговых льгот и преференций (нулевая ставка по налогу на прибыль, пониженная ставка налога на добавленную стоимость, специальные налоговые режимы, льготное налогообложение земельных участков и др.).

Адресная поддержка малых форм хозяйствования в 2020 г. осуществлялась в рамках ведомственного проекта (предоставление субсидии). Всего в 2020 г. получателями грантовой поддержки в рамках направлений «стимулирующей» субсидии стало 2161 КФХ (план 1447 ед.) и 174 кооператива (план - 132 ед.).

Кроме того, совместно с АО «Россельхозбанк» проведена работа по синхронизации мер грантовой поддержки малых форм хозяйствования с кредитными продуктами банка, разработаны типовые решения для кредито- вания проектов по развитию мясного и молочного скотоводства, введены специальные кредитные продукты для вновь созданных хозяйств, не имеющих кредитной истории. Разрабатываются специальные кредитные решения для реализации проектов «Агропрогресс», проектов по плодоводству и ягодоводству, овцеводству, развитию мини-теплиц. Для увеличения объема сбыта сельхозпродукции малых форм хозяйствования в 2020 г. расширены целевые направления расходования грантов СПоК - включены оборудование для маркировки продукции, спецтранспорт для ее перевозки, дополнительное оборудование для хранения и транспортировки. Кроме того, в рамках механизма льготного кредитования стало возможным приобретение малыми формами хозяйствования торговых объектов и торгового оборудования.

Одним из основных ресурсов сельскохозяйственного производства является земля. В 2020 г. посевные площади сельскохозяйственных культур составили 79,9 млн га, что почти в 1,5 раза ниже уровня 1991 г., то есть 35,6 млн га сельскохозяйственных земель на данный момент не обрабатываются. За период 2017-2019 гг. в Российской Федерации введено в оборот 2,5 млн га земель, однако за тот же период из оборота выведено 1,6 млн га пашни. С учетом выбытия пашни ввод в оборот за 2017-2019 гг. составил 0,9 млн га. Сокращение пашни происходит как по естествен- 
ным причинам (деградация от ветровой и водной эрозии), так и в результате хозяйственной деятельности людей (нарушение севооборотов, истощение, загрязнение от техногенных факторов, пренебрежение нормами внесения средств защиты растений и удобрений, переход части земель из сельскохозяйственных в земли населенных пунктов или промышленные). По оценкам экспертов, без проведения высокозатратных культуртехнических и мелиоративных работ в оборот возможно вернуть в ближайшее время до 20 млн га сельскохозяйственных земель.

В настоящее время селекция и семеноводство выступают не только одной из основ продовольственной безопасности страны, но и драйвером роста экспортного потенциала. Сложившаяся в последние годы ситуация с широким применением семян зарубежной селекции вызывает серьезную обеспокоенность. Обеспеченность отечественными семенами по некоторым культурам критически низкая: по сахарной свекле составляет менее 1 \%, картофелю - менее $10 \%$, подсолнечнику $26 \%$, яровому рапсу - $32 \%$, кукурузе, сое и овощным культурам - менее 50 \%. Даже по тем культурам, которые всегда мало зависели от импорта, наблюдается негативная динамика. Так, за 2013-2019 гг. доля отечественных семян яровой пшеницы снизилась на $14,4 \%$, ярового ячменя - на 21,6 \%, подсолнечника - на $24 \%$, картофеля - на 49,3\%. Только за 2019 г. импортных семян яровой пшеницы высеяно больше на 297 тыс. тонн, картофеля - на 278 тыс. тонн, ярового ячменя - на 216 тыс. тонн, подсолнечника - на 4,5 тыс. тонн. Кроме того, требует внимания вопрос качества семенного материала. По оценкам экспертов, ежегодно высевается около 30 \% некачественных семян, в том числе зарубежной селекции, что приводит к снижению урожайности и росту потерь сельскохозяйственной продукции [Аналитический вестник ..., 2021]. В связи с этим развитие отечественных селекции и семеноводства должно являться одной из приоритетных государственных задач.

Основными причинами снижения доли высеваемых российских семян являются низкая конкурентоспособность отечественных сортов сельскохозяйственных культур и недо- статочные объемы их производства. На селекционном процессе в нашей стране серьезно сказывается технологическое отставание: применяемые устаревшие методы селекции требуют много времени и высоких трудозатрат для получения и воспроизводства нового сорта (до 15 лет), при этом сложно добиться высокой устойчивости получаемых свойств. Кроме того, зарубежные фирмы предлагают в комплексе с сортовыми семенами полную технологию возделывания сельскохозяйственных культур, включающую удобрения и средства защиты, наиболее эффективные для данного конкретного сорта. В связи с этим зарубежные сорта более устойчивы к болезням и вредителям, обладают высокими показателями урожайности и качества получаемого сырья. Лишь некоторые отечественные селекционные организации начинают прорабатывать вопрос предоставления с посевным материалом комплекса агрохимикатов для конкретного сорта или группы сортов. При сохранении сложившихся тенденций возникает угроза потери отечественных сортов, восстановление которых в зависимости от применяемых технологий может занять от 7 до 15 лет. Поэтому актуальным становится вопрос о создании дополнительной системы мер государственной поддержки, стимулирующих приобретение семян отечественной селекции [Аналитический вестник ..., 2021]. Также важно активизировать проведение технической и технологической политики в АПК, оказывать содействие распространению передового опыта внедрения в сельскохозяйственное производство перспективных технологий и применения высокопроизводительных современных машин.

Одной из важнейших проблем российских селекционно-семеноводческих организаций является материально-техническое обеспечение. По оценкам экспертов, в селекционной деятельности на территории Российской Федерации в настоящее время участвует свыше 100 организаций, боле 90 \% из которых государственные. В настоящее время селекционеры имеют в своем распоряжении технику, с момента выпуска которой прошло более 30 лет. Это физически и морально устаревшие машины, не способные обеспечить требуемые качественные показатели технологи- 
ческих операций. Вопрос повышения технической оснащенности селекционных и семеноводческих хозяйств, обеспечения их специализированными машинами и оборудованием должен являться прерогативой государства. Для повышения конкурентоспособности отечественных семян и обеспечения ими российских сельскохозяйственных товаропроизводителей необходимо принять комплекс оперативных мер, направленных на обновление материально-технической базы селекционных учреждений, развитие кадрового потенциала и повышение привлекательности профессии, внедрение инновационных селекционных технологий, государственное стимулирование сельскохозяйственных товаропроизводителей на приобретение семян отечественной селекции. В частности, применение инновационных технологий в селекции и семеноводстве требует разработки новых машин, отвечающих современным требованиям. Все эти мероприятия требуют проработки и серьезной финансовой поддержки со стороны государства.

Основным техническим средством производства в сельском хозяйстве является трактор. Непрерывный процесс сокращения тракторного парка страны в течение последних трех десятилетий стал основной причиной критически низкого технического обеспечения агропромышленного комплекса России.

В 2020 г. объем производства российской сельскохозяйственной техники составил 149 млрд рублей, что на 29,6 \% больше, чем за 2019 год. Доля российской техники на внутреннем рынке в настоящее время, по предварительной оценке, составляет $58 \%$, что на 4 п.п. больше, чем в 2019 году (см. таблицу).

Ключевым механизмом государственной поддержки спроса на российскую сельскохозяйственную технику являются субсидии производителям сельскохозяйственной техники. В 2020 г. было предусмотрено для этой цели 14 млрд рублей, указанные сред- ства выплачены предприятиям в полном объеме.

Специализированная техника и оборудование, в том числе для сельского хозяйства, может приобретаться в рамках программы льготного лизинга. В 2020 г. на реализацию мероприятия было выделено 4 млрд рублей, что позволило реализовать на льготных условиях порядка 6,8 тыс. единиц специализированной техники и оборудования.

Существующих объемов производства тракторов внутри страны явно недостаточно для удовлетворения текущей потребности в технике. Для формирования оптимального парка сельскохозяйственных тракторов, позволяющего производить технологические операции в соответствии с агротехническими требованиями, необходимо в несколько раз увеличить производство и обеспечить возможность приобретения сельскохозяйственными товаропроизводителями современных отечественных тракторов. Для этого необходимо развивать отечественное конкурентоспособное производство тракторов, имеющих высокие показатели качества, надежности, топливной экономичности и экологичности [Аналитический вестник ... , 2021, c. 82].

Если не принять кардинальных мер по обеспечению формирования оптимального состава тракторного парка, то отечественное сельское хозяйство в связи с продолжающимся нарушением агротехнических сроков и низким качеством исполнения технологических операций продолжит терять и недополучать миллионы тонн продукции.

Анализ структуры приобретения сельскохозяйственных тракторов в 2019 г. показывает, что доля отечественных моделей составляет только $30,9 \%$, а наибольшую долю рынка - $46 \%$ - занимают тракторы, собираемые из тракторокомплектов МТЗ. Таким образом, больше двух третей из всего объема

Таблиияа

\section{Информация о производстве российской сельскохозяйственной техники}

в 2017-2020 гг.

\begin{tabular}{|l|c|c|c|c|c|}
\hline \multicolumn{1}{|c|}{ Показатель } & 2017 г. & 2018 г. & 2019 г. & 2020 г. & Изм. 2020 г. / 2019 г., \% \\
\hline $\begin{array}{l}\text { Производство (с НДС), } \\
\text { млрд руб. }\end{array}$ & 107,2 & 108,2 & 115 & 149 & $+29,6$ \\
\hline
\end{tabular}

Примечание. Составлено по: [Аналитический вестник ..., 2021, с. 43]. 
приобретаемых тракторов - импортные [Аналитический вестник ..., 2021, с. 82].

Продвижению и внедрению инноваций в отечественное сельскохозяйственное производство препятствуют низкие качество и эксплуатационные характеристики отечественных комплектующих, а также ограниченность их ассортимента. Так, государственная политика сельскохозяйственного машиностроения в контексте проведения научно-исследовательских и опытно-конструкторских работ повысит качество техники, что, в свою очередь, должно привести к повышению урожайности сельскохозяйственных культур и содействию импортозамещения.

\section{Заключение}

Таким образом, современные экономические реалии диктуют свои условия для решения проблем конкурентоспособности российского продовольствия и других сфер АПК.

Разумеется, создание универсального механизма стимулирования импортозамещения в АПК не представляется возможным по причине специфичности регионов, обусловленных природно-ресурсным потенциалом, сложившимися условиями производства, уровнем спроса на продукцию АПК. Необходимо выработать общую модель, синхронизировав действия всех уровней власти, бизнес-структур и непосредственно предприятий АПК во взаимоувязке с программно-целевыми механизмами (муниципальные, областные и федеральные программы) и нормативно-правовым обеспечением, которое соответствовало бы современным тенденциям развития российской экономики.

Финансирование традиционно продолжает быть локомотивом развития ресурсной базы предприятий АПК. Поэтому целесообразно продолжать наращивать потенциал финансовых мер поддержки отраслей АПК, обеспечивающих ускоренное импортозамещение в контексте стимулирования государственно-частного партнерства (вопросы логистики, обмен опытом, инвестиционные проекты). Развитие данного инструмента способствует снижению бюджетной нагрузки.
Министерству промышленности и торговли рекомендовано принять дополнительные меры для стимулирования создания на территории Российской Федерации сельскохозяйственных машиностроительных производств полного цикла, выпускающих машины и оборудование, отвечающие современным потребностям аграрного сектора экономики (прежде всего тракторов малой и средней мощности, техники для селекции, семеноводства, питомниководства, садоводства и виноградарства) и поддержания спроса на российскую машиностроительную продукцию [Аналитический вестник ..., , 2021, с. 86]. Логичными, на наш взгляд, являются разработка новых и совершенствование действующих региональных программ по поддержке приобретения техники сельскохозяйственными производителями.

Предлагается усиление налоговых стимулирующих механизмов: налоговые инвестиционные льготы на производство конкурентоспособных аналогов импортной сельскохозяйственной техники, налоговые преференции российским производителям продовольствия, внедряющим прогрессивные технологии и новейшие виды сырья, предоставление инновационно активным предприятиям по переработке сырья и выпуску готовой пищевой продукции налоговых каникул и установление гибкой шкалы ставок по уплачиваемым им налогам. В части налогообложения целесообразно сохранить введенные в связи пандемией ставки по страховым взносам для малого и среднего бизнеса в $15 \%$, а для поддержки КФХ и индивидуальных предпринимателей необходимо объявить налоговые каникулы сроком еще на 1 год. Также целесообразно отменить налоги для вновь образуемых КФХ сроком на 5 лет [Аналитический вестник ..., 2021, с. 55].

В части стимулирования инвестиционной деятельности в АПК необходимо увеличить объемы и создать условия для доступности инвестиционных ресурсов. При этом особо важным представляется увеличение объемов субсидирования вновь привлекаемых инвестиционных кредитов. Также считаем возможным расширение направлений грантовой поддержки и перечня целевого льготного краткосрочного кредитования. 


\section{СПИСОК ЛИТЕРАТУРЫ}

Аналитический вестник № 9 (769) «О ходе реализации государственной программы развития сельского хозяйства и регулирования рынков сельскохозяйственной продукции, сырья и продовольствия». - М., 2021. - Электрон. текстовые дан. - Режим доступа: http:/council.gov.ru/ media/files/d4ApG8Uw6BKngDd1JO3WsPDg IlAj1AEd.pdf. - Загл. с экрана.

Баранов, Э. Ф. Импортозамещение в динамике внешней торговли товарами в Российской Федерации / Э. Ф. Баранов, Н. Н. Волкова, А. Ф. Лобзов // Экономические науки. 2013. - № 7 (104). - С. 7-11.

Березинская, О. Б. Производственная зависимость российской промышленности от импорта и механизм стратегического импортозамещения / О. Б. Березинская, А. Л. Ведев // Вопросы экономики. - 2015. - № 1. - С. 103-115.

Идрисов, Г. И. Импортозамещение в России в $1998-$ 2007 годах / Г. И. Идрисов, П. А. Кадочников, С. Г. Синельников-Мурылев. - Электрон. текстовые дан. - Режим доступа: https:/www.iep. ru/ru/publikatcii/publication/7234.html. - Загл. с экрана.

Лявина, М. Ю. Агропродовольственное импортозамещение в России: стратегия и механизм реализации : дис. ... д-ра экон. наук / Лявина Мария Юрьевна. - Саратов, 2021. - 439 с.

Лявина, М. Ю. Импортозамещение: возникновение термина и его генезис / М. Ю. Лявина // Аграрный научный журнал. - 2017. - № 6. - С. 85-88.

Национальный доклад о ходе и результатах реализации в 2020 году Государственной программы развития сельского хозяйства и регулирования рынков сельскохозяйственной продукции, сырья и продовольствия. - М., 2021. Электрон. текстовые дан. - Режим доступа: https://mcx.gov.ru/upload/iblock/953/953ee7405 fb0ebba38a6031a13ec0021.pdf. - Загл. с экрана.

Смирнов, Д. А. Методы организации инновационного развития электросетевого комплекса России на основе импортозамещения оборудования : дис. ... канд. экон. наук / Смирнов Дмитрий Александрович. -СПб., 2012. - 188 с.

Старовойтова, О. В. Импортозамещение в условиях малой открытой экономики : автореф. дис. ... канд. экон. наук / Старовойтова Ольга Викторовна. - Минск, 2011. - 23 с.

Сучкова, Н. А. Импортозамещение в продовольственном секторе России : автореф. дис. ... канд. экон. наук / Сучкова Наталья Альбертовна. - М., 2009. - 28 с.

Фальцман, В. К. Форсирование импортозамещения в новой геополитической обстановке / В. К. Фаль- цман // Проблемы прогнозирования. - 2015. № 1. - С. 22-32.

Федосеева, Г. А. Сущность и развитие теории импортозамещения / Г. А. Федосеева // Известия Санкт-Петербургского государственного экономического университета. - 2015. № 3 (93). - С. 144-148.

Чернова, О. А. Оценка потенциала импортозамещения АПК ЮФО / О. А. Чернова, И. В. Митрофанова // Вестник Волгоградского государственного университета. Серия 3, Экономика. Экология. - 2018. - Т. 20, № 1. - С. 40-54. DOI: https://doi.org/10.15688/jvolsu3.2018.1.5.

\section{REFERENCES}

Analiticheskij vestnik № 9 (769) «O hode realizacii gosudarstvennoj programmy razvitiya sel'skogo hozyajstva $i$ regulirovaniya rynkov sel'skohozyajstvennoj produkcii, syr'ya $i$ prodovol'stviya» [Analytical Bulletin No. 9 (769) "On the Progress in the Implementation of the State Program for the Development of Agriculture and the Regulation of Markets for Agricultural Products, Raw Materials and Food"]. Moscow, 2021. URL: http://council.gov.ru/media/files/ d4ApG8Uw 6BKngDd1JO3WsPDgIlAj1AEd.pdf.

Baranov E.F., Volkova N.N., Lobzov A.F. Importozameshchenie $\mathrm{v}$ dinamike vneshnej torgovli tovarami v Rossijskoj Federacii [Import Substitution in the Dynamics of Foreign Trade of Goods in the Russian Federation]. Ekonomicheskie nauki [Economic Sciences], 2013, no. 7 (104), pp. 7-11.

Berezinskaya O.B., Vedev A.L. Proizvodstvennaya zavisimost' rossijskoj promyshlennosti ot importa i mekhanizm strategicheskogo importozameshcheniya [Production Dependence of Russian Industry on Imports and Mechanism of Strategic Import Substitution]. Voprosy ekonomiki, 2015, no. 1, pp. 103-115.

Idrisov G.I., Kadochnikov P.A., Sinel'nikov-Murylev S.G. Importozameshchenie $v$ Rossii v 19982007 godah [Import Substitution in Russia in 1998-2007]. URL: www.iep.ru/ru/publikatcii/ publication/7234.html.

Lyavina M.Yu. Agroprodovol'stvennoe importozameshchenie v Rossii: strategiya i mekhanizm realizacii: dis. ... d-ra. ekon. nauk [Agri-Food Import Substitution in Russia: Strategy and Implementation Mechanism. Dr. econ. sci. diss.]. Saratov, 2021. 439 p.

Lyavina M.Yu. Importozameshchenie: vozniknovenie termina i ego genezis [Import Substitution: Emergence of the Term and Its Genesis]. 
Agrarnyj nauchnyj zhurnal [The Agrarian Scientific Journal], 2017, no. 6, pp. 85-88.

Nacional'nyj doklad o hode $i$ rezul tatah realizacii $v$ 2020 godu Gosudarstvennoj programmy razvitiya sel'skogo hozyajstva i regulirovaniya rynkov sel'skohozyajstvennoj produkcii, syr'ya $i$ prodovol'stviya [National Report on the Progress and Results of the Implementation of the State Program for the Development of Agriculture and Regulation of Agricultural Products, Raw Materials and Food Markets in 2020]. Moscow, 2021. URL: https://mcx.gov.ru/ upload/iblock/953/953ee7405fb0ebba38a6031a 13ec0021.pdf.

Smirnov D.A. Metody organizacii innovacionnogo razvitiya elektrosetevogo kompleksa Rossii na osnove importozameshcheniya oborudovaniya: dis. ... kand. ekon. nauk [Methods of Organization of Innovative Development of the Electric Grid Complex of Russia on the Basis of Import Substitution of Equipment. Cand. econ. sci. diss.]. Sankt Petersburg, 2012. 188 p.

Starovojtova O.V. Importozameshchenie v usloviyah maloj otkrytoj ekonomiki: avtoref. dis. ... kand. ekon. nauk [Import Substitution in a Small Open Economy. Cand. econ. sci. abs. diss.]. Minsk, 2011. 23 p.
Suchkova N.A. Importozameshchenie v prodovol'stvennom sektore Rossii: avtoref. dis. ... kand. ekon. nauk [Import Substitution in the Food Sector of Russia. Cand. econ. sci. abs. diss.]. Moscow, 2009. 28 p.

Fal'cman V.K. Forsirovanie importozameshcheniya v novoj geopoliticheskoj obstanovke [Forcing Import Substitution in a New Geopolitical Environment]. Problemy prognozirovaniya, 2015, no. 1, pp. 22-32.

Fedoseeva G.A. Sushchnost' i razvitie teorii importozameshcheniya [The Essence and the Development of Import Substitution]. Izvestiya Sankt-Peterburgskogo gosudarstvennogo ekonomicheskogo universiteta, 2015, no. 3 (93), pp. 144-148.

Chernova O.A., Mitrofanova I.V. Ocenka potenciala importozameshcheniya APK YuFO [Assessment of Potential of Import Substitution of AgroIndustrial Complex of the Southern Federal District]. Vestnik Volgogradskogo gosudarstvennogo universiteta. Seriya 3, Ekonomika. Ekologiya [Science Journal of Volgograd State University. Global Economic System], 2018, vol. 20, no. 1, pp. 40-54. DOI: https://doi.org/10.15688/jvolsu3. 2018.1.5.

\section{Information About the Authors}

Natalya V. Gorshkova, Doctor of Sciences (Economics), Associate Professor, Head of the Department of Theory of Finance, Credit and Taxation, Volgograd State University, Prosp. Universitetsky, 100, 400062 Volgograd, Russian Federation, gorshkovanv@volsu.ru, https://orcid.org/0000-0003-0586-9509

Ekaterina A. Shkarupa, Candidate of Sciences (Economics), Associate Professor, Department of Theory of Finance, Credit and Taxation, Volgograd State University, Prosp. Universitetsky, 100, 400062 Volgograd, Russian Federation, shkarupaea@volsu.ru, https://orcid.org/0000-0002-9986-2641

Aleksej V. Eltoncev, Postgraduate Student, Department of Theory of Finance, Credit and Taxation, Volgograd State University, Prosp. Universitetsky, 100, 400062 Volgograd, Russian Federation, alek.elton2016@yandex.ru, https://orcid.org/0000-0001-5687-7520

\section{Информация об авторах}

Наталья Валерьевна Горшкова, доктор экономических наук, доцент, заведующая кафедрой теории финансов, кредита и налогообложения, Волгоградский государственный университет, просп. Университетский, 100, 400062 г. Волгоград, Российская Федерация, gorshkovanv@volsu.ru, https://orcid.org/0000-0003-0586-9509

Екатерина Александровна Шкарупа, кандидат экономических наук, доцент кафедры теории финансов, кредита и налогообложения, Волгоградский государственный университет, просп. Университетский, 100, 400062 г. Волгоград, Российская Федерация, shkarupaea@volsu.ru, https://orcid.org/0000-0002-9986-2641

Алексей Викторович Елтонцев, аспирант кафедры теории финансов, кредита и налогообложения, Волгоградский государственный университет, просп. Университетский, 100, 400062 г. Волгоград, Российская Федерация, alek.elton2016@yandex.ru, https://orcid.org/0000-0001-5687-7520 